\title{
Phytochemical and Mineral Content in Leaves, Stem and Bark of Pterocarpus Santalinoides (Nturukpa) from Afikpo, Ebonyi State, Nigeria
}

\section{"OGBONNA, PC; IDUMAH, MC}

\author{
"Department of Environmental Management and Toxicology, Michael Okpara University of Agriculture Umudike, P.M.B. 7267 Umuahia, \\ Abia State, Nigeria \\ *Corresponding author email: ogbonna_princewill@yahoo.com ; +2348063402809
}

\begin{abstract}
The study assessed the phytochemical and mineral content in leaves, stem and bark of Pterocarpus santalinoides sampled from three (3) stands at Itim Autonomous Community in Afikpo, Ebonyi State. Qualitative and quantitative determination of the phytochemical (alkaloids, flavonoids, tannins, saponins and Phenols) content was carried out using standard methods while the mineral content were determined using Atomic Absorption Spectrometry (AAS 210 VGP, Buck Scientific, Inc., East Norwalk, USA). The result of the qualitative analysis revealed that the bark extract had the highest alkaloid with high degree of precipitation (++) compared to all other extracts. The result of the quantitative analysis showed that the highest values of alkaloids $(2.24 \%)$, flavonoids $(4.40 \%)$, saponins $(10.51 \%)$, and tannins $(0.13 \%)$ were obtained in the leaves of Pterocarpus santalinoides and these values were significantly $(\mathrm{P}<0.05)$ higher than values recorded in bark $(1.82,3.33,8.21$ and $0.05 \%)$, and stem $(1.56,3.12,6.97$ and $0.03 \%)$. Similarly, the results of mineral content showed that Fe $(35.93 \mathrm{mg} / 100 \mathrm{~g}), \mathrm{Na}(23.37 \mathrm{mg} / 100 \mathrm{~g}), \mathrm{Ca}(1.48 \mathrm{mg} / 100 \mathrm{~g}), \mathrm{Mg}(17.47 \mathrm{mg} / 100 \mathrm{~g})$ and $\mathrm{P}$ $(10.11 \mathrm{mg} / 100 \mathrm{~g})$ were highest in the leaves. The values of phytochemicals and minerals present in the leaves of Pterocarpus santalinoides indicate that the plant has immense health benefit, thus, it can be explored for manufacturing of drugs in pharmaceutical industries.
\end{abstract}

\section{DOI: https://dx.doi.org/10.4314/jasem.v22i8.1}

Copyright: Copyright $\odot 2018$ Ogbonna and Idumah. This is an open access article distributed under the Creative Commons Attribution License (CCL), which permits unrestricted use, distribution, and reproduction in any medium, provided the original work is properly cited.

Dates: Received: 24 May 2018; Revised: 16 June: 2018; Accepted: 11 July 2018

Key words: Phytochemical, mineral, leaves, bark, stem

In Nigeria, plants play important role in maintenance of good health since they (i.e. plants) are cheaper source of medicine especially to the rural dwellers that cannot afford the high prices of drugs. The usefulness of plant based products in medicine is due to the presence of bioactive substances such as alkaloids, flavonoids, phenolic compounds, steroids, resins and other secondary metabolites and are capable of producing definite physical action in the body (Bishnu et al., 2009).

Herbal plants have not only provided food and shelter but also served the humanity to cure different dysfunctions. Indeed, a wide array of diseases including life threatening diseases such as cancer, diabetes, hypertension etc. are being treated successfully with medicinal plants (Ahmed, 2007). It has been used extensively in the developing countries as a more available and affordable alternative to pharmaceutical drugs. The use of plant species, plants extracts or plant-derived pure chemicals to treat disease in Nigeria has become a therapeutic modality that has stand the test of time.
Minerals are essentially required for osmotic adjustment and to activate enzymes (Aslam et al., 2005). Man do not synthesize minerals rather, we obtain minerals from our diet (Anjorin et al., 2010) and major minerals such as $\mathrm{P}, \mathrm{K}, \mathrm{Ca}, \mathrm{Na}$ and $\mathrm{Mg}$ function in cell metabolism and acid-base balance, as well as aid in prevention and treatment of diseases (Prasad, 1993).

In South east Nigeria, the fresh, tender leaves of Pterocarpus santalinoides is used as vegetable in soup making. However, no much scientific validation has been carried out on the species for its medicinal uses. To address this gap, the study is aimed to determine the qualitative and quantitative phytochemical analysis and assessment of mineral content of leaves, stem and bark of Pterocarpus santalinoides.

\section{MATERIALS AND METHODS}

The study area: The study on phytochemical and mineral contents in Pterocarpus santalinoides was carried out in Itim Autonomous Community in Afikpo North Local Government Area. Afikpo North is a local government and the second largest urban area in Ebonyi State. It is located in the southern part of 
Ebonyi State and is bordered to the North by the town of Akpoha, to the South by Unwana, to the South West by Edda, to the East by Cross River and to the West by Amasiri. It has an area of $240 \mathrm{~km}^{2}$ and has a population of 156,611 at the 2006 census (Afikpo Today Magazine, 2007). It is located at $5^{\circ} 53 \mathrm{~N}$ to $7^{\circ} 56 \mathrm{E}$ latitude and $5^{\circ} 88 \mathrm{~N}$ to $7^{\circ} 93 \mathrm{E}$ longitude. It is a hilly area despite occupying a region low in altitude, which rises $350 \mathrm{ft}$ above sea level (Afikpo Today Magazine, 2007). It is a transitional area between open grassland and tropical forestland and has an average annual rainfall of seventy-seven inches $(198 \mathrm{~cm})$.

Sample collection and preparation: Fresh leaves, stem and bark of Pterocarpus santalinoides was collected randomly with cleaned secateurs from different branches of the three stands of the plant species. Each samples from each stand was bagged separately in envelops, labeled well and taken to the laboratory. The samples from each stand was separated and washed to remove sand and dust particles and dried to dryness at atmospheric temperature for 14 days. Each sample of leaves, stem and bark was blended separately with an electric blender, sieved and stored in air tight plastic bottles for analysis. Distilled water was used for extraction. $10 \mathrm{~g}$ each of the dry plant materials were soaked in water at room temperature for two days. The extracts was filtered using a Whatmann filter paper No. $42(125 \mathrm{~mm})$, and then through cotton wool (Ajuru et al., 2017). The extracts was evaporated into dryness using a hot water bath for 72 hours, and were then stored in the refrigerator for further use.

Phytochemical tests: Preliminary qualitative phytochemical screening of extract was carried out to determine the presence of secondary metabolites using the method described by Harbone (1998) and Parekh and Chanda (2007). Alkaloids were qualitatively detected by dragendroff reagent (potassium bismuth iodide), flavonoid by Benedict's solutions (Adamu et al., 1970), saponin by frothing test, tannin by wohler's test and phenol by ferric chloride solution as described by Ajuru et al. (2017).

Quantitatively alkaloids, flavonoids were extracted using method of Brain and Turner (1975). Extraction of saponin was carried out by the procedure described by Sharma et al. (1982), total phenol and tannins constituents in extract and leaves of Pterocarpus santalinoides was determined spectrophotometrically (Okwu, 2005) by Folin-Ciocalteu method (Jahan et al., 2011).

Determination of mineral contents: Calcium and Magnesium was determined by titration method using murexide and Eriochrome black $\mathrm{T}$ indicator, respectively. Amount of $\mathrm{Na}$ and $\mathrm{K}$ was determined by flame photometer (Greenburg et al., 1992). The concentration of $\mathrm{P}$ and $\mathrm{Fe}$ was determined with atomic absorption spectrophotometer, AAS (210 VGP, Buck Scientific, Inc., East Norwalk, USA) after calibrating the equipment with different standard concentrations) following the conditions described in AOAC (1990). The analysis was conducted in triplicate.

Experimental design and statistical analysis: A simple factorial experiment in a randomized complete block design was used to determine the phytochemical and mineral content of leaves, stem and bark in three replicates. The data collected is subjected to one way analysis of variance (ANOVA) using Statistical Package for Social Sciences (SPSS) v.16 and separation of means done with Duncan Multiple Range Test (DMRT) at $\mathrm{P}<0.05$.

\section{RESULTS AND DISCUSSION}

The present study showed that the extracts of leaves, stem and bark contained alkaloids, flavonoids, saponins, phenols and tannins (Table 1). Compared to all other extracts, the bark extract had the highest alkaloids with high degree of precipitation (++). However, the values obtained for flavonoids, saponins, phenols and tannins were equal for leaves, stem and bark.

Table 1: Qualitative phytochemical analysis in leaves, stem and bark of Pterocarpus santalinoides

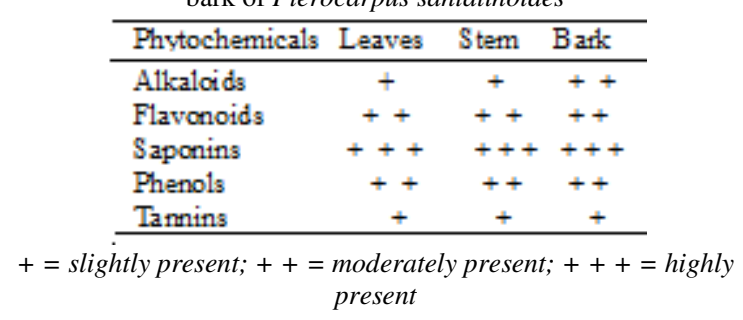

The results on the phytochemical content in leaves, stem and bark of Pterocarpus santalinoides is presented in Table 2. The results indicate that the highest and lowest content of the phytochemicals: alkaloids (2.24 and $1.56 \%$ ), flavonoids (4.40 and 3.12 $\%)$, and saponins (10.51 and $6.97 \%$ ) were obtained in leaves and stems, respectively. Indeed, the highest content of alkaloids (2.24\%), flavonoids (4.40\%), saponins $(10.51 \%)$ and tannins $(0.13 \%)$ were observed in the leaves and these values are significantly $(\mathrm{P}<0.05)$ higher than values obtained in the bark $(1.82,3.33,8.21$ and $0.05 \%)$ and stem (1.56, $3.12,6.97$ and $0.03 \%$ ), respectively. The high content of these phytochemicals in leaves suggest that the use of Pterocarpus santalinoides leaves as source of vegetable soup and medicine will enhance the health and nutritional value of the body. The values of 
alkaloids (2.24\%), flavonoid (4.40\%), saponin (10.51 $\%)$, and phenol $(0.16 \%)$ in this study is higher than $0.75,0.50,0.75$ and 0.07 reported for alkaloid, flavonoid, saponin, and phenol in Gongronema latifolium (Ajuru et al., 2017). Similarly, the level of alkaloids in leaves of Pterocarpus santalinoides in this study is higher than the values reported by Eni et al., 2010 in Piper guineense. There was no significant difference $(\mathrm{P}>0.05)$ in the values obtained for phenols in leaves $(0.16 \%)$, stem $(0.34 \%)$, and bark $(0.01 \%)$, respectively. However, the values obtained for tannins $(0.13 \%)$ in leaves is significantly $(\mathrm{P}<0.05)$ higher than values observed in bark $(0.05 \%)$ and stem $(0.03$ $\%)$. From the results, Pterocarpus santalinoides can be recommended for the use of manufacturing of drugs in pharmaceutical industries since it has high content of phytochemicals in leaves.

\begin{tabular}{|c|c|c|c|c|c|}
\hline \multirow{2}{*}{$\begin{array}{l}\text { Plant } \\
\text { parts }\end{array}$} & \multicolumn{5}{|c|}{ Phytochemicals \% } \\
\hline & Alkaloids & Flavonoids & Saponins & Phenol & Tannins \\
\hline Leaves & $2.24^{\mathrm{a}}$ & $4.40^{\mathrm{a}}$ & $10.51^{\mathrm{a}}$ & $0.16^{\mathrm{a}}$ & $0.13^{\mathrm{a}}$ \\
\hline Stem & $1.56^{\mathrm{c}}$ & $3.12^{\mathrm{c}}$ & $6.97^{\mathrm{c}}$ & $0.34^{\mathrm{a}}$ & $0.03^{\mathrm{b}}$ \\
\hline Bark & $1.82^{\mathrm{b}}$ & $3.33^{\mathrm{b}}$ & $8.21^{\mathrm{b}}$ & $0.10^{\mathrm{a}}$ & $0.05^{\mathrm{b}}$ \\
\hline
\end{tabular}

Table 3 Mineral contents in leaves, stem and bark of Pterocarpus santalinoides

\begin{tabular}{lllllll}
\hline Plant parts & \multicolumn{5}{c}{ Minerals $(\mathrm{mg} / 100 \mathrm{~g})$} \\
\cline { 2 - 7 } & $\mathrm{Fe}$ & $\mathrm{Na}$ & $\mathrm{K}$ & $\mathrm{Ca}$ & $\mathrm{Mg}$ & $\mathrm{P}$ \\
\hline Leaves & $35.93^{\mathrm{a}}$ & $23.37^{\mathrm{a}}$ & $15.57^{\mathrm{a}}$ & $1.48^{\mathrm{a}}$ & $17.47^{\mathrm{a}}$ & $10.11^{\mathrm{a}}$ \\
Stem & $20.03^{\mathrm{c}}$ & $15.80^{\mathrm{c}}$ & $13.43^{\mathrm{b}}$ & $1.11^{\mathrm{c}}$ & $9.17^{\mathrm{c}}$ & $4.29^{\mathrm{c}}$ \\
Bark & $23.90^{\mathrm{b}}$ & $18.42^{\mathrm{b}}$ & $11.73^{\mathrm{c}}$ & $1.24^{\mathrm{b}}$ & $12.04^{\mathrm{b}}$ & $4.84^{\mathrm{b}}$ \\
\hline
\end{tabular}

$a, b, c$ means that there are significantly difference at $P<0.05$.

The result on the mineral content in leaves, stem and bark of Pterocarpus santalinoides is presented in Table 3. The results show that the highest and the lowest content of the minerals: Fe (35.93 and 20.03 $\mathrm{mg} / 100 \mathrm{~g}), \mathrm{Na}(23.37$ and $15.80 \mathrm{mg} / 100 \mathrm{~g}), \mathrm{Ca}(1.48$ and $1.11 \mathrm{mg} / 100 \mathrm{~g}), \mathrm{Mg}(17.47$ and $9.17 \mathrm{mg} / 100 \mathrm{~g}$ ) and $\mathrm{P}$ (10.11 and $4.29 \mathrm{mg} / 100 \mathrm{~g}$ ) were obtained in leaves and stem respectively. The level of Fe (35.93 $\mathrm{mg} / 100 \mathrm{~g}), \mathrm{Na}(23.39 \mathrm{mg} / 100 \mathrm{~g})$ and $\mathrm{P}(10.11 \mathrm{mg} / 100$ g) obtained in leaves is higher than values reported by Ando and Elma (2007) for Gnetum africana. The use of the leaves of Pterocarpus santalinoides as source of food will enhance the nutritional value of our health.

Conclusion: From this study, it can be concluded that the highest content of the phytochemicals (alkaloids, flavonoids, saponins, phenol and tannins) were obtained in the leaves of Pterocarpus santalinoides. Similarly, the highest content of the minerals ( $\mathrm{Fe}, \mathrm{Na}$, $\mathrm{Ca}, \mathrm{Mg}$, and $\mathrm{P}$ ) were observed in its leaves. Thus, Pterocarpus santalinoides can be utilized in the pharmaceutical industries for the manufacturing of drugs for treatment of various diseases and ailment.

Acknowledgement: We wish to acknowledge the Technologists at the National Root Crops Research Institute Umudike for the determination of the phytochemical and mineral content in leaves of Pterocarpus santalinoides.

\section{REFERENCES}

Adamu, J; Jhonson, R; Nilcox, C F (1970). Laboratory experiments, inorganic chemistry. The Meamillian Company, London, UK.

Ahmed, SS (2007). Medicinal wild plants from Lahore-Islamabad motorway (M-2), Pakistan. Pak. J. Bot. 39(2): 355-375.

Ajuru, MG; Williams, LF; Ajuru, G (2017). Qualitative and quantitative phytochemical screening of some plants used in ethnomedicine in the Niger Delta Region of Nigeria. J. Food Nutr. Sci. 5(5): 198-205.

Anjorin, TS; Ikokoh, P; Okolona, S (2010). Mineral composition of Moringa oleifera leaves, pods, and seed from two region in Abuja, Nigeria. Int. J. Agric. Biol. 12: 431 - 434.

AOAC (1990). Official methods of analysis. Association of Official Analytical Chemists. Arlington, VA, USA.

Aslam, M; Anwar, F; Nadeem, R; Rashid, U; Kazi, TG; Nadeem, M (2005). Mineral composition of Moringa oleifera leaves and pods from different regions of Punjab, Pakistan. Asian J. Plant Sci. 4: $417-421$.

Bishnu, JU; Sunil, L; Anuja, S (2009). Antibacterial properties of different medicinal plants; Ocimum 
santum, Cinnamomum zeylanicum, Xanthoxylim arimatum, and Origanum masorana. J. Sci. Engr. Technol. 5: 143 - 150.

Brain, KR; Turner, JD (1975). The practical evaluation of phyto pharmaceutical. Wright Scientia Bristill, USA.

Eni, AO; Ibukunoluwa, AO; Oranusi, US (2010). Microbial quality of fruits and vegetables sold in Sango Ota, Nigeria. Afr. J. Food Sci. 4(5): 291296.

Greenburg, AE; Clesseeri, LS; Eatin, AD (1992). Standard methods for examination of water and waste water. American Public Health Association, Washington, USA.

Harborne, JB (1998). Phytochemical Methods: A Guide to Modern Techniques of Plant Analysis. Chapman and Hall, London, UK.
Jahan, N; Rehman, KU; Ali, S; Bhatti, IA (2011). Antioxidant activity of gemmo therapeutically treated indigenous medicinal plants. Asian J. Chem. 23: 3461 - 3470.

Okwu, DE (2005). Phytochemicals, vitamins and mineral contents of two Nigerian medicinal plants. Int. J. Molec. Med. Adv. Sci. 1: 375 - 381.

Parekh, J; Chanda, S (2007). Antibacterial and phytochemical studies on twelve species of Indian medicinal plants. Afr. J. Biomed. Res., 10: 175 181.

Prasad, AS (1993). Essential and toxic elements in human health and disease: an Update. Wiley-Liss. New York.

Sharma, SC; Sati, OP; Chand, R (1982). Steroidal constituents of different parts of Asparagus curillus Buch. Ham. Curr. Sci. 51: 280 - 281. 